M. Milanov ${ }^{1}$, Yu. Leshchenko ${ }^{1}$, A. Yelizieva ${ }^{1}$, R. Artiukh ${ }^{2}$

${ }^{1}$ National Aerospace University named after N. Ye. Zhukovskii "Kharkiv Aviation Institute", Ukraine

${ }^{2}$ State Enterprise "National Design \& Research Institute of Aerospace Industries", Kharkiv, Ukraine

\title{
DEVELOPMENT OF THE APPLICATION OF INFORMATION SUPPORT OF MEDICAL DIAGNOSTIC AND TREATMENT CENTERS
}

\begin{abstract}
The subject of the article's research is the model and technology of information support for the medical diagnostic and treatment center (MDTC). The goal is to reduce costs and the time to organize the work a medical diagnostic and treatment center by applying and developed models and an information system. The following problems were solved in the paper: to conduct an analytical review of existing integrated medical information systems; to develop a model for the functioning of the MDTC; to develop software for the subsystem of information support for the MDTC functioning, including the local drug formulary. Methods of the theory of algorithms, automaton models and technologies for software applications development were used to solve these problems. The following results were obtained. Existing medical systems that allow automating the business processes of medical institutions are analyzed, their advantages and disadvantages are designated. The functional subsystems of the MDTC that automate the functions of the departments of a medical institution are designated. Automation models and expressions of the algebra of relationships have been obtained for the main departments of the MDTC, that allow to present in a formalized form the process of a medical institution functioning. The model of the functioning of the MDTC is formed on the basis of the theory of automate and an expression of the algebra of relations is obtained that describes in a formalized form the work of the medical center. The structure of the software system for information support of the MDTC is proposed. The navigation system of the web-resource of MDTC was developed. A use-case diagram was developed showing the functionality of the main categories of users. Conclusions: the information support of the MDTC will reduce the time for patient care due to the organized sequence of actions of department staff and reduce the risk of errors in diagnosis due to mathematical and statistical processing of the results of the diagnostics. A drug formulary was developed, which allows the patient to receive recommendations on the use of drugs based on the entered search parameters.
\end{abstract}

Keywords: medical diagnostic and treatment center; automation models; algebra of algorithms; information support system; use case diagram; web resource; drug formulary.

\section{Introduction}

Today, the intensive use of information technology (IT) in medicine is becoming more widespread. It is used to solve both the general problems characteristic of health care in general and the tasks of a specific health care facility (HCF), taking into account all the peculiarities of its functioning [1]. The main goal of health informatization is to create new IT at all levels and new medical computer technologies that improve the quality of health care and assist in the implementation of the basic function of public health, that is, increase the duration of active life. The introduction of medical information systems improves diagnosis in selected medical treatment centers and affects the overall health care system in the country [2-7].

Analysis of recent studies and publications. Today, the delivery of quality medical services is impossible without information technologies that automate many HCF functions. It should be noted that there are different types of medical information systems (MIS) depending on the levels of management (Table 1). Table 2 shows the comparative characteristics of medical information systems of Ukraine, which belong to the level of hospitals, highlights their advantages and disadvantages $[8-10]$. These medical information systems (MISs) create a single HCF information space that enables the collection of data on the performance of all departments; manage the staff and financial resources of the institution [11 - 13]. However, the implementation of IIA has the following features:

- significant cost;

- compliance of the HCF organizational structure with the MIS structure;

- inability to integrate with other software applications implemented in HCF;

- the need to configure MIS according to the HCF specialization.

Most hospitals use the automated workplaces (AWRs) of doctors, but the task of integrating AWRs into a single system of a medical facility arises. Therefore, the main functions of the following departments should be automated in HCF:

- the attending physician;

- reception office;

- medical consultants;

- diagnostic department;

- information and reference.

\section{Table 1 - Classification of MIS}

\begin{tabular}{|l|l|l|l|}
\hline Level of management & \multicolumn{1}{|c|}{ Basic level } & \multicolumn{1}{c|}{ Level of hospitals } & \multicolumn{1}{c|}{ Territorial level } \\
\hline Types of MIS & - reference; & - MIS of consulting centers; & - MIS of strategic importance; \\
& - consultative and diagnostic; & - screening systems; & - MIS of specialized medical \\
& $-\begin{array}{l}\text { hardware and software com- } \\
\text { plexes; }\end{array}$ & - MIS of HCF; \\
& - the doctor's AWP. & - MIS for research institutes. & $-\begin{array}{l}\text { computer telecommunication } \\
\text { systems. }\end{array}$ \\
\hline
\end{tabular}


Table 2 - Comparative analysis of medical information systems of Ukraine

\begin{tabular}{|c|c|c|}
\hline $\begin{array}{c}\text { Name } \\
\text { of the system }\end{array}$ & Possibilities & Disadvantages \\
\hline "Dr.Eleks" & $\begin{array}{l}\text { - electronic medical card of the patient; } \\
\text { - doctor's office; } \\
\text { - editor of document templates; } \\
\text { - tracking statistics; } \\
\text { - presence of the module of the registry; } \\
\text { - } \text { availability of modules for personnel and reporting; } \\
\text { - possibility of integration with laboratory networks and diagnostic equipment. }\end{array}$ & $\begin{array}{l}\text { - the work requires staff } \\
\text { training; } \\
\text { - system configuration } \\
\text { is required to automate } \\
\text { the operation of spe- } \\
\text { cific divisions. }\end{array}$ \\
\hline "EMCIMED" & $\begin{array}{l}\text { - maintenance of electronic medical history of a network of institutions; } \\
\text { - planning and optimization of the hospital process; } \\
\text { - information support and support of hospital diagnostic processes; } \\
\text { - informational support of work of the staff of the medical institution; } \\
\text { - } \text { solving problems of an administrative, economic and financial nature. }\end{array}$ & $\begin{array}{l}\text { - the complexity of add- } \\
\text { ing solutions to spe- } \\
\text { cific problems; } \\
\text { - no separate module } \\
\text { for the registry. }\end{array}$ \\
\hline "Unimed"-7 & $\begin{array}{l}\text { - } \text { workplace of family doctor; } \\
\text { - } \text { registration of patients; } \\
\text { - } \text { system of processing, storage and prompt access to patient cards; } \\
\text { - } \text { possibility of adjustment for a specific medical institution; } \\
\text { - } \text { automated workplace for ultrasound diagnostics; } \\
\text { - integration of specialists' workplaces into a single hospital medical system. }\end{array}$ & $\begin{array}{l}\text { - absence of AWP for } \\
\text { medical specialists; } \\
\text { - - staff training is re- } \\
\text { quired for work. }\end{array}$ \\
\hline "K-MIS" & $\begin{array}{l}\text { - - maintaining an electronic medical history; } \\
\text { - - accounting for laboratory research; } \\
\text { - - formation of a schedule of doctors ' appointments; } \\
\text { - - report generation; } \\
\text { - - monitoring of the institution's activities. }\end{array}$ & $\begin{array}{l}\text { - - the work requires } \\
\text { staff training; } \\
\text { - - the complexity of } \\
\text { making changes. }\end{array}$ \\
\hline
\end{tabular}

Based on the analysis, it is possible to determine the structure of an automated system of information support of a medical institution, which consists of the following subsystems, regardless of the type of its specialization:

- subsystem of the institution's registry;

- online consultation subsystem;

- laboratory research subsystem;

- patient electronic journal;

- statistics subsystem.

\section{Materials and methods}

The following departments are part of a typical medical treatment and diagnostic center (MDTC) of any specialization:

- registration;

- laboratory;

- center for statistical analysis;

- online consulting service;

- departments of specialist doctors.

The article proposes to describe the processes of functioning of MDTC departments with the help of automatic models that can be formally presented in this way [14-23]:

$$
A=\left(X, f, a_{0}, F\right),
$$

where $X$ - a set of output symbols of the automaton; $f-$ transfer function; $a_{0}-$ a set of initial states of the automaton, since $\left\{a_{0}, a_{1}, \ldots, a_{n}\right\}$ is the set of states of the automaton; $F$ - a set of final states.

Let us present the process of work of these departments using the algebra of relations, which allows us to formally describe the MDTC processes on the basis of a set of states [24-30]. The process of the registry is shown in the form of an automatic machine model (Fig. 1).

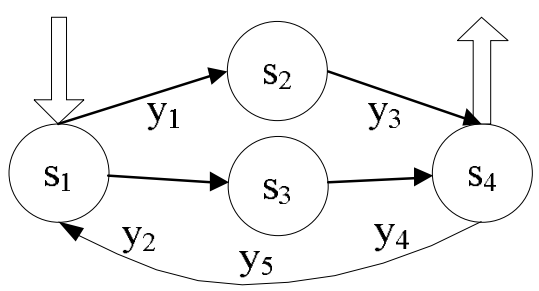

Fig. 1. Automatic model

of the process of functioning of the registry

Fig. 1 shows states of the automation model that are:

$s_{1}$ - referral of the patient to MDTC;

$s_{2}$ - entry to a specialist doctor;

$s_{3}$ - appearance of a new electronic card of the patient;

$s_{4}$ - formation of medical records.

The functions of automatic model transitions are:

$y_{1}$ - search for patient information in the journal;

$y_{2}$ - formation of the schedule of admission of a specialist doctor;

$y_{3}$ - Filling in the MDTC New Patient Information;

$y_{4}$ - correction of patient information;

$y_{5}$ - the possibility of repetition.

Let's write the equation in the algebra of relations:

$$
\begin{gathered}
f_{1}=y_{1} f_{2} \vee y_{2} f_{2}=\left(y_{1} \vee y_{2}\right) f_{2} ; \\
f_{2}=y_{3} f_{4} ; \\
f_{3}=y_{4} f_{4} ; \quad f_{4}=y_{5} f_{1} .
\end{gathered}
$$

The function of the model is defined as a regular expression of the algebra of relations:

$$
\left.f_{1}=\left(y_{1} \vee y_{2}\right) y_{3} y_{4} y_{5}\right)^{*} \text {. }
$$

We present in the form of an automatic model the process of work of the MDTC laboratory (Fig. 2). 


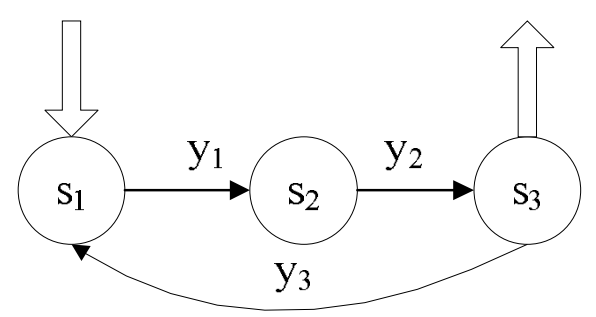

Fig. 2. Automatic model of laboratory work

Fig. 2 shows that states of the automation model are: $s_{1}$ - receipt of records of laboratory tests;

$s_{2}$ - preparation for admission;

$s_{3}$ - formation of medical records.

The functions of automatic model transitions are:

$y_{1}$ - accounting for reagents;

$y_{2}$ - formation of a log of statistics;

$y_{3}$ - possibility of repetition.

Let us write the equation in the algebra of relations:

$$
f_{1}=y_{1} f_{2} ; \quad f_{2}=y_{2} f_{3} ; \quad f_{3}=y_{3} f_{1} .
$$

The operation of the registry model describes the regular expression of the algebra of relations:

$$
f_{1}=\left(y_{1} y_{2} y_{3}\right)^{*} \text {. }
$$

Let us present the process of work of the center of statistical analysis in the form of an automatic model (Fig. 3).

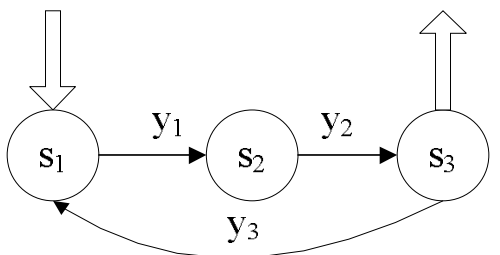

Fig. 3. Automatic model of functioning of the center of statistical analysis

In Fig. 3, the states of the automaton model are:

$s_{1}$ - receipt of ultrasound results;

$s_{2}$ - receipt of expert opinions;

$s_{3}$ - production of statistical reports.

Functions of automatic model transitions are:

$y_{1}$ - obtaining an analytical conclusion based on

ultrasound results using data collection and analysis methods;

$y_{2}$ - obtaining probabilistic estimation of presence of a certain disease by means of mathematical apparatus;

$y_{3}-$ the possibility of repetition.

We write the equation in the algebra of relations:

$$
f_{1}=y_{1} f_{2} ; f_{2}=y_{2} f_{3} ; \quad f_{3}=y_{3} f_{1} .
$$

The operation of the statistical analysis center model of operation describes the regular expression of the algebra of relations:

$$
f_{1}=\left(y_{1} y_{2} y_{3}\right)^{*} \text {. }
$$

Here is the process of MDTC operation in the form of an automatic model (Fig. 4).

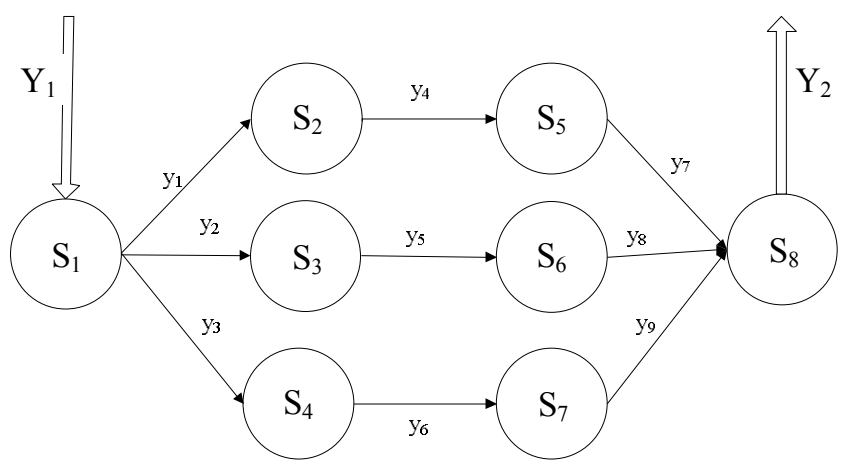

Fig. 4. MDTC automatic model

Fig. 4 shows states and functions of transitions:

$s_{1}$ - patient information;

$s_{2}$ - change of schedule of admission of a specialist doctor;

$s_{3}$ - change of schedule of reception of laboratory;

$s_{4}$ - changing the timetable for online consultations;

$s_{5}$ - change of information in the patient's electronic journal;

$s_{6}-$ accounting for reagents;

$s_{7}-$ record of the result of the doctor's appointment;

$s_{8}$ - preparation of reporting documents;

$Y_{1}$ - referral of the patient to MDTC;

$Y_{2}$ - storing patient information in the MDTC database;

$y_{1}$ - processing the record with a specialist;

$y_{2}$ - processing the recording to the laboratory;

$y_{3}$ - processing an appointment for an online consultation;

$y_{4}$ - reception by a specialist doctor (keeping the patient's electronic journal);

$y_{5}$ - conducting laboratory tests;

$y_{6}$ - production of statistical reports;

$y_{7}, y_{8}, y_{9}$ - formation of journals, statistical documentation.

The result is an expression of the algebra of relations that describes the formalized work of MDTC:

$$
f=Y_{1}\left(y_{1} y_{4} y_{7} \vee y_{2} y_{5} y_{8} \vee y_{3} y_{6} y_{9}\right) Y_{2} .
$$

It should be mentioned that each disjunction describes the work of a particular department of the institution. The formalized representation of the MDTC workflow in the form of an automated model allows to take into account the changing processes (states) and functions of departments of a medical institution (transition functions). Regular expressions of the algebra of relations determine the sequence of processes performed by the staff of the institution. Automation of these processes will reduce the time needed to serve patients and reduce the risk of errors in the examination.

\section{Results of the studies}

For automation of these functions (Fig. 4) the MDTC information support system is proposed, its structure consists of the following modules (Fig. 5):

- software (SW) for statistical and mathematical data processing; 
- registry software;

- MDTC Website;

- laboratory research software;

- a database that communicates with the database administration server;

- information and reference system.

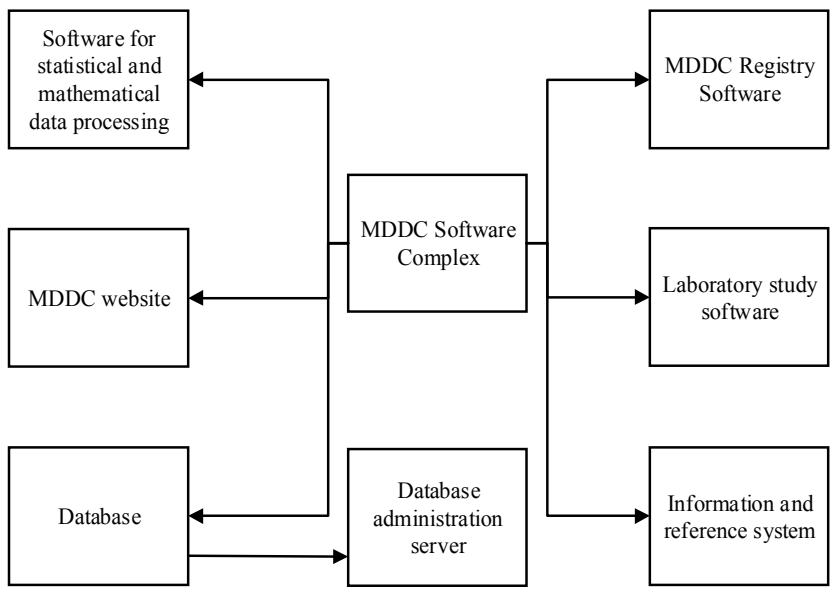

Fig. 5. Structure of the MDTC information support software system

Thus, MIS combines the types of systems of the basic level and the level of the medical institution (Table 1). Apache was selected as the server-trust for administering the database, the main advantages of which are:

- support for different operating systems;

- cross-platform;

- reliability and flexibility of configuration;

- possibility of connection of external modules for data provision;

- possibility of modification of error messages;

- the ability to process configuration files (server, virtual host, directory level);

- availability of module loading system.

MYSQL database management system (DBMS) has been selected for storing and processing information, the main advantages of which are:

- free support;

- multithreading, ie the ability to simultaneously support multiple requests; tions

- optimize connections with multiple data connec-

- support for up to 16 keys in the table, each of which can have up to 15 fields;

- case insensitivity;

- easy to manage tables.

The Computer Health Information System has a search engine and the ability to process information from multiple medical fields. The electronic directory has the following record structure:

- name of the disease;

- a concise description;

- additional classifications;

- etiology and risk factors;

- diagnostics (screening, complaints and anamnesis, laboratory tests, consultations of specialists, etc.);

- differential diagnosis;
- treatment and rehabilitation;

- prognosis and possible complications;

- prevention (recommendations, medical examination, etc.).

However, the focus is on developing a site for MDTC information support. Fig. 6 shows the navigational structure of the MDTC Web Resource, which consists of the main menu, the search system, the link and the registration box.

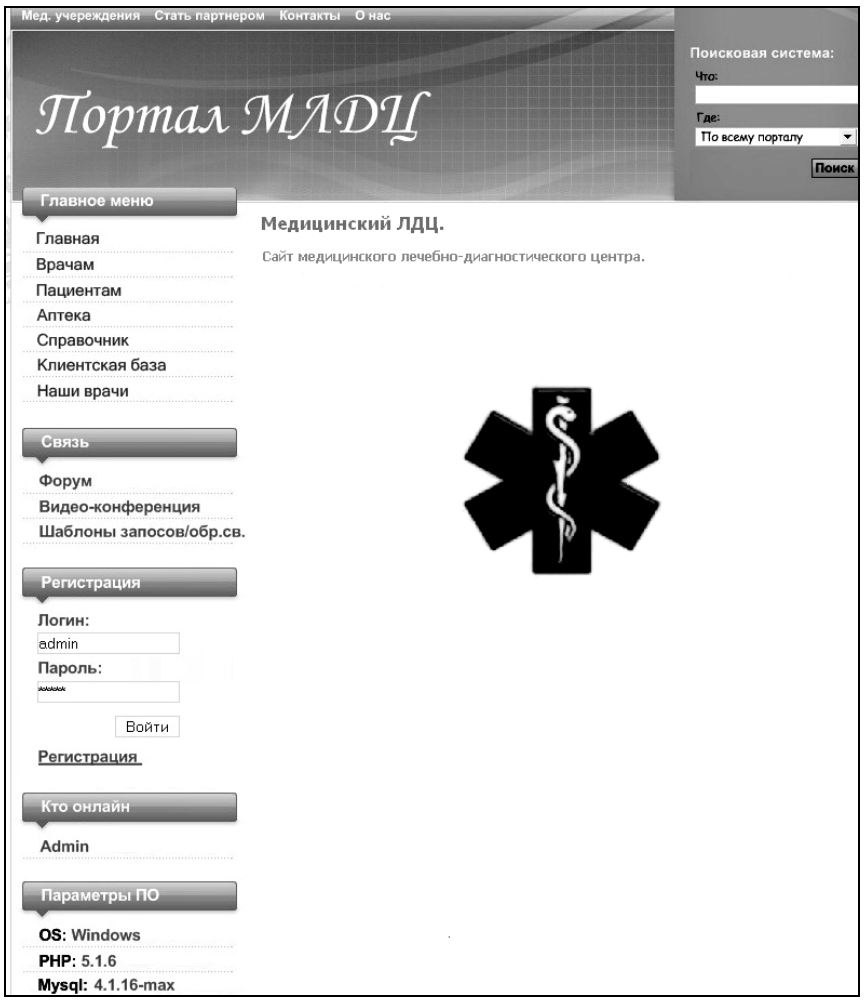

Fig. 6. Navigation structure of the MDTC Web resource

It should be noted that the site also displays information about the software settings and the type of user currently online. The chosen scheme of implementation allows to add new materials, create sections, issue permissions to closed site resources, change the appearance with the most automated administrative section (Fig. 7).

The interface includes all the software tools that provide quality management and support for the site. Fig. 8 shows a module manager that allows to select sections of the site.

With the module manager, it is possible to choose the order of the post, its access and the position on the site. The web application is implemented using HTML (HyperText Markup Language) technologies [31], CSS (Cascading Style Sheets) [32] and Java Script [33].

One of the main sections of the MDTC Web resource is the work of an on-line diagnostic consulting service, the functionality of which is presented by two software modules - a forum and a component for hosting an Internet conference. The forum is a virtual space that offers a set of discussion sections. The work of the forum is to create topics in sections and further discussion within these topics, which are a thematic guest book. The forum hierarchy is structured as 
follows: section $\rightarrow$ topics $\rightarrow$ posts. Working with the videoconference reception $\log$ is an electronic calendar that identifies MDTC workdays with unrestricted online consultation time.

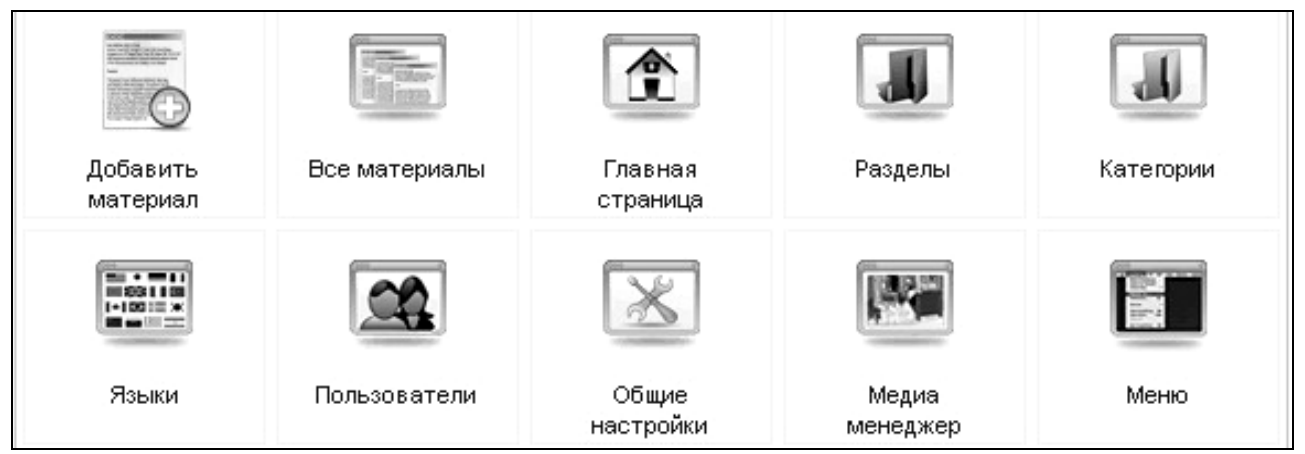

Fig. 7. Interface of automatic administration system

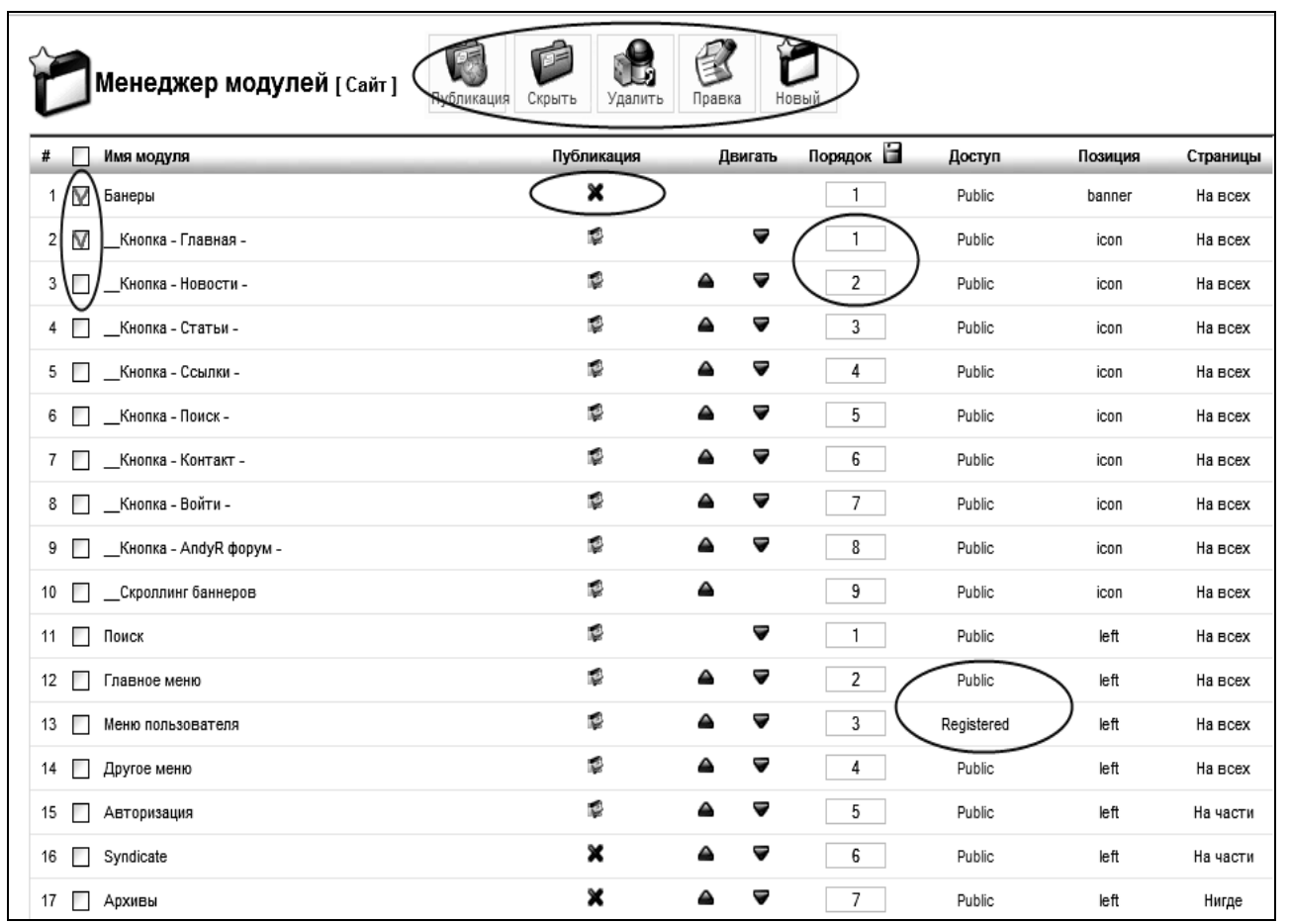

Fig. 8. The module manager

Fig. 9 shows a precedent diagram showing the basic functionality of a web application for four categories of users: user, registered user, moderator and administrator. Admin features differ from the moderator's ability to access the site management system. The moderator can view and edit the information provided on the site using the appropriate module. This simplifies the process of editing information (adding, deleting, and adjusting) without the need for site-making skills. The registered user can get a remote consultation of MDTC specialist through the relevant software modules.

Consider in more detail the electronic form of hospitals, which belongs to the information and reference system. With its help, the user is able to search for medicines by certain parameters (Fig. 10). The user interface looks like the following tables:

- departments;

- groups;

- subgroups;

- special group;

- the main table - that is medicines.

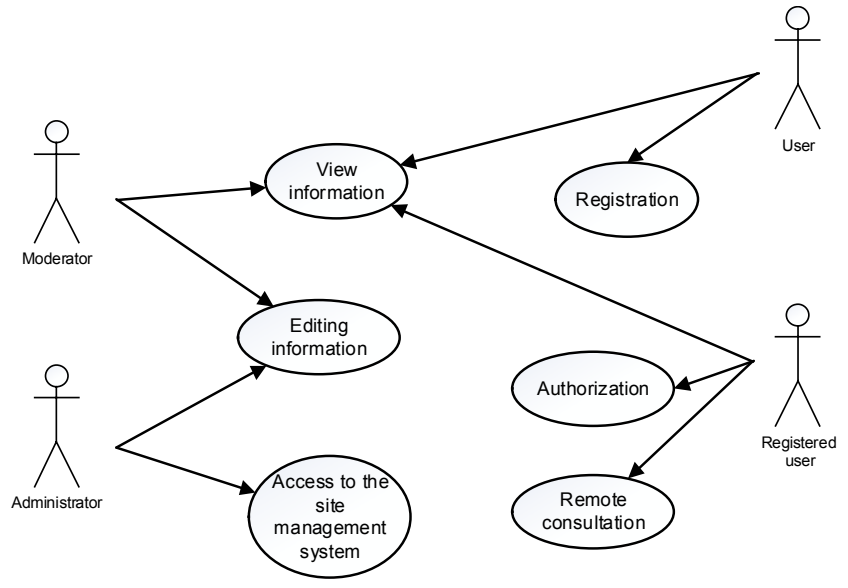

Fig. 9. Case diagram

The File menu has a search function. To search for a drug, the user must enter the name of the medicinal product in the appropriate field and go to the search results. Editing of the results is also available. 


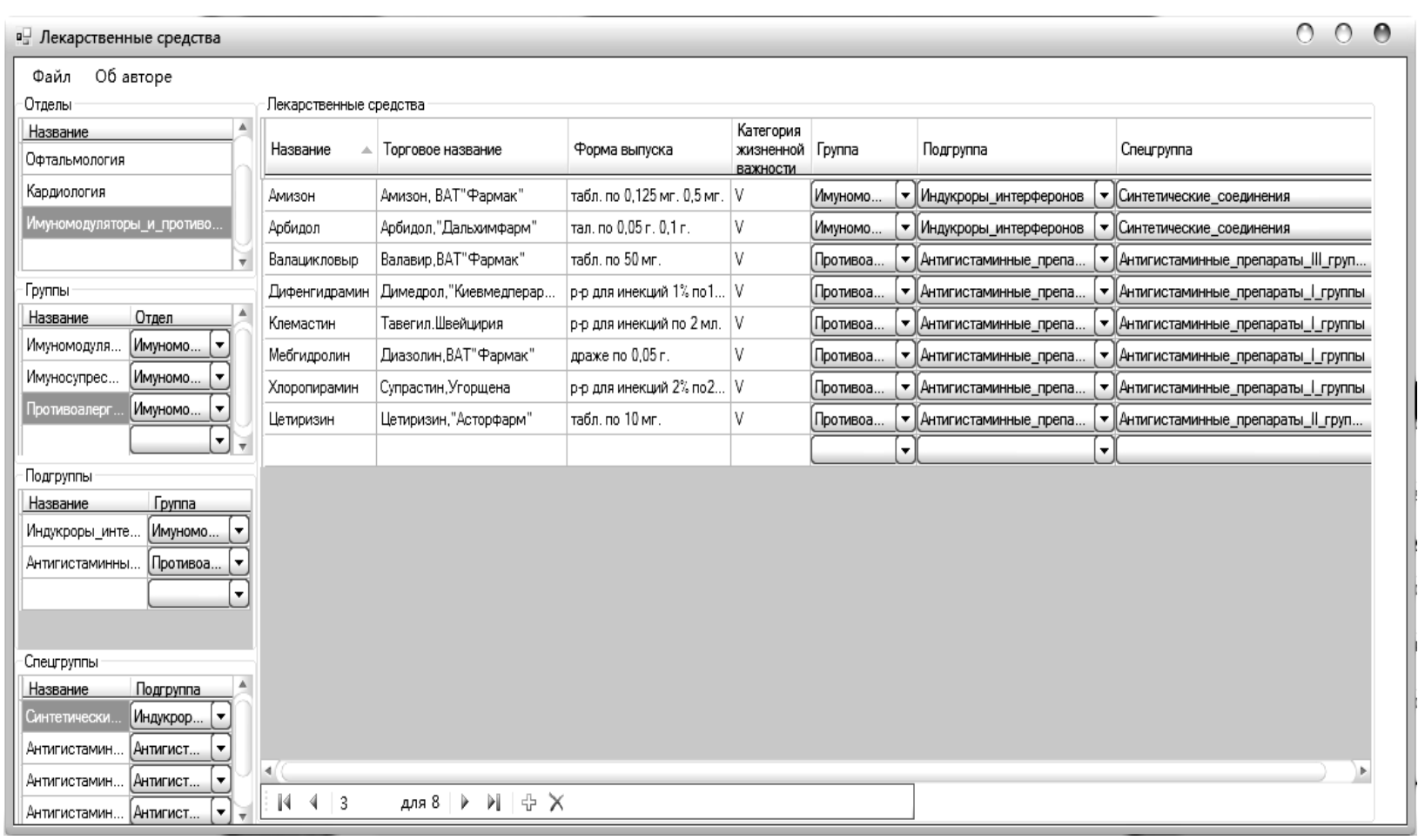

Fig. 10. The main form window

\section{Conclusions}

The article analyzes the existing medical systems, on the basis of which the functions of the MDTC information support system are highlighted. Formed automatic models and expressions of algebra of relations allow us to describe in a formalized form the processes of functioning of branches of MDTC. The structure of information support system of medical hospitaldiagnostic institution is proposed and web-resource is developed. In addition, a medicines form has been de- veloped to provide advice on the use of certain types of drugs.

The scientific novelty of the article is a formalized representation of MDTC processes in the form of algebra of relations, which allows determining the sequence of functions performed by employees of medical institutions of different specialization.

The practical value is the ability to use the developed web-resource for MDTC information support, which allows automating the basic functions of the institution, regardless of its specialization.

\section{REFERENCES}

1. Morris F. Collen and W. Ed Hammond (2015), "Development of Medical Information Systems", The History of Medical Informatics in the United States, pp. 123-206, DOI: https://doi.org/10.1007/978-1-4471-6732-7 3

2. Popov V.A., Milanov M.V. and Reva S.A. (2014), "Analysis of methods and models of construction of the ramified informative system medical curatively - diagnostic center", Radio electronic and computer systems, No. 2 (66), pp. 146-154.

3. Belo, O. (2011), "Improving diagnosis processes through multidimensional analysis in medical institutions", Technology and Medical Sciences, TMSi 2010 - Proc. of the 6th Int. Conf. on Technology and Medical Sciences 2011, pp. 135-141.

4. Were, M.C., A. Siika, P.O. Ayuo, L. Atwoli and Esamai F. (2015), "Building Comprehensive and Sustainable Health Informatics Institutions in Developing Countries: Moi University Experience", Studies in Health Technology and Informatics, Vol. 216, pp. 520-524, DOI: https://doi.org/10.3233/978-1-61499-564-7-520

5. Anokwa, Y., Ribeka, N., Parikh, T., Borriello, G. and Were, M.C. (2012), "Design of a Phone-Based Clinical Decision Support System for Resource-Limited Settings”, ACM International Conference Proceeding Series, P. 13-24. DOI: https://doi.org/10.1145/2160673.2160676

6. Lamy, M., Pereira, R., Ferreira, J.C., Vasconcelos, J.B., Melo, F. and Velez, I. (2019), "Extracting Clinical Information from Electronic Medical Records", Advances in Intelligent Systems and Computing, Vol. 806, pp. 113-120, DOI: https://doi.org/10.1007/978-3-030-01746-0 13

7. Kyburz, P., Gfeller, S., Bürkle, T. and Denecke, K. (2019), "Exchanging Appointment Data among Healthcare Institutions", Studies in Health Technology and Informatics, Vol. 260, pp. 33-40, DOI: https://doi.org/10.3233/978-1-61499-971-3-33

8. (2019), Site of company "Medical information systems", available at: https://www.momed.ua/ru

9. (2019), Site of company "Medexpert", available at: http://medexpert.ua/services/meditsinskie-sistemy

10. (2019), Site of company "Medspravka", available at: https://www.medsprava.com.ua/article/1084-meditsinskie-informatsionnye-sistemy-rus

11. (2019), Site of company "K-MIS Medical Information System", available at: https://kai.ua/ru/products/k-mis/

12. Yakubovska, S., Vysotska, O. and Timofeev, V. (2017), "Mathematical support of the intelligent information system of assessing the object state", Innovative Technologies and Scientific Solutions for Industries, No. 2 (2), pp. 93-99, DOI: $\underline{\text { https://doi.org/10.30837/2522-9818.2017.2.093 }}$ 
13. Mandrikova, L., Posternakova, V., Krasovska, I. and Symovych, T. (2019), "Problems of identification in information systems", Advanced Information Systems, Vol. 3, No. 2, pp. 5-9, DOI: https://doi.org/10.20998/2522-9052.2019.2.01

14. (2019), Medical information systems: how to choose your own, available at: https://imed.co.ua/ru/menedzhment/medicinskie-informacionnye-sistemy-kak-vybrat-svoyu

15. Alferova, Z.V. (1973), Theory of algorithms, Statistics, Moscow, 164 p.

16. Kovalenko, A. and Kuchuk, H. (2018), "Methods for synthesis of informational and technical structures of critical application object's control system", Advanced Information Systems, 2018, Vol. 2, No. 1, pp. 22-27, DOI: https://doi.org/10.20998/2522-9052.2018.1.04

17. Kuchuk, G.A., Kovalenko, A.A. and Lukova-Chujiko, N.V. (2017), "A method for minimizing the average latency of packets in the virtual connections of the cloud service support network", Control, navigation and communication systems, PNTU, Poltava, No. 2 (42), pp. 117-120.

18. Svyrydov, A., Kuchuk, H., Tsiapa, O. (2018), "Improving efficienty of image recognition process: Approach and case study", Proceedings of 2018 IEEE 9th International Conference on Dependable Systems, Services and Technologies, DESSERT 2018, pp. 593-597, DOI: http://dx.doi.org/10.1109/DESSERT.2018.8409201

19. Ruban, I., Kuchuk, H. and Kovalenko A. (2017), "Redistribution of base stations load in mobile communication networks", Innovative technologies and scientific solutions for industries, No 1 (1), P. 75-81, DOI : https://doi.org/10.30837/2522-9818.2017.1.075

20. Kuchuk, G., Kovalenko, A., Komari, I.E., Svyrydov, A. and Kharchenko, V. (2019), "Improving big data centers energy efficiency: Traffic based model and method", Studies in Systems, Decision and Control, vol 171, Kharchenko, V., Kondratenko, Y., Kacprzyk, J. (Eds.), Springer Nature Switzerland AG, pp. 161-183, DOI: http://doi.org/10.1007/978-3-030$00253-48$

21. Kuchuk G., Nechausov S., Kharchenko, V. "Two-stage optimization of resource allocation for hybrid cloud data store", International Conference on Information and Digital Technologies. Zilina, 2015. P. 266-271. DOI: http://dx.doi.org/10.1109/DT.2015.7222982

22. Donets, V., Kuchuk, N. and Shmatkov, S. (2018), "Development of software of e-learning information system synthesis modeling process", Advanced Information Systems, Vol. 2, No 2, pp. 117-121, DOI: https://doi.org/10.20998/25229052.2018.2.20

23. Merlac, V., Smatkov, S., Kuchuk, N. and Nechausov A. (2018), "Resourses Distribution Method of University e-learning on the Hypercovergent platform", Conf. Proc. of 2018 IEEE $9^{\text {th }}$ International Conference on Dependable Systems, Service and Technologies. DESSERT'2018, Ukraine, Kyiv, May 24-27, pp. 136-140, - DOI: http://dx.doi.org/10.1109/DESSERT.2018.8409114

24. Leshchenko Y., Yelizieva A. (2020), "System Model for Decision Making Support in Logistics and Quality Management Business Processes of Manufacture Enterprise". In: Ageyev D., Radivilova T., Kryvinska N. (eds) Centric Business and Applications. Lecture Notes on Data Engineering and Communications Technologies, Vol. 42. Springer, Cham, P. 93-113. https://doi.org/10.1007/978-3-030-35649-1 5

25. Chalyi, S. and Leshchynskyi, V. (2019), "Knowledge representation in the recommendation system based on the white box principle", Advanced Information Systems, 2019, Vol. 3, No. 3, pp. 82-85, DOI: https://doi.org/10.20998/25229052.2019.3.12

26. Mukhin, V., Kuchuk, N., Kosenko, N., Kuchuk, H. and Kosenko, V. (2020), ’Decomposition Method for Synthesizing the Computer System Architecture, Advances in Intelligent Systems and Computing", AISC, vol. 938, pp 289-300, DOI: https://doi.org/10.1007/978-3-030-16621-2 27

27. Kuchuk, N., Mozhaiev, O., Mozhaiev, M., Kuchuk, H. (2017), "Method for calculating of R-learning traffic peakedness", 2017 4th International Scientific-Practical Conference Problems of Infocommunications Science and Technology, PIC S and T 2017 - Proceedings, pp. 359-362, DOI: https://doi.org/10.1109/INFOCOMMST.2017.8246416

28. Mozhaiev, M., Kuchuk, N. and Usatenko, M. (2019), "The method of jitter determining in the telecommunication network of a computer system on a special software platform", Innovative technologies and scientific solutions for industries, Vol. 4 (10), pp. 134-140. doi: https://doi.org/10.30837/2522-9818.2019.10.134

29. Bakurova, A., Pasichnyk, M. and Tereschenko, E. (2019), "Fuzzy modeling of verbal information for production systems", Innovative technologies and scientific solutions for industries, No. 4 (10), pp. 5-13, doi: https://doi.org/10.30837/2522$\underline{9818.2019 .10 .005}$

30. Malyeyeva, O., Yelizyeva, A., Kosenko, N. Nevliudova, V. (2018) "Information technologies of supporting decision-making on managing the procurement of a manufacturing enterprise", Innovative Technologies and Scientific Solutions for Industries, No. 3 (5), pp. 57-66. DOI: https://doi.org/10.30837/2522-9818.2018.5.057.

31. (2019), HTML5Book. HTML and HTML5, "Description of tags by main sections", available at: https://html5book.ru/html5semantic-elements

32. (2019), HTML5Book, CSS and CSS3, available at: https://html5book.ru/css-css3/

33. (2019), Javascript. What is javascript really? Client-side web APIs, available at: https://developer.mozilla.org/ru/docs/Learn/Getting_started_with the_web/JavaScript basics

Received (Надійшла) 19.11.2019

Accepted for publication (Прийнята до друку) 23.01.2020

\section{ВідОмості ПРО АвтоРів / АвоUт тHE AUTHORS}

Міланов Михайло Володимирович - кандидат технічних наук, доцент, доцент кафедри комп'ютерних наук та інформаційних технологій, Національний аерокосмічний університет ім. М. Є. Жуковського «XАI», Харків, Україна; Mykhailo Milanov - Candidate of Technical Sciences, Associate Professor, Associate Professor of Computer Sciences and Information Technologies Department, National Aerospace University named after N. Ye. Zhukovskiy " KhAI", Ukraine; e-mail: milanov1954@gmail.com; ORCID ID: https://orcid.org/0000-0001-6269-5985. 
Лещенко Юлія Олександрівна - кандидат технічних наук, доцент кафедри комп'ютерних наук та інформаційних технологій, Національний аерокосмічний університет ім. М. Є. Жуковського «XАI», Харків, Україна;

Yuliia Leshchenko - Candidate of Technical Sciences, Associate Professor of Computer Sciences and Information Technologies Department, National Aerospace University named after N. Ye. Zhukovskiy " KhAI", Kharkiv, Ukraine; e-mail: j.leshhenko@khai.edu; ORCID ID: https://orcid.org/0000-0001-9232-697X.

Слізєва Аліна Володимирівна - кандидат технічних наук, доцент кафедри комп’ютерних наук та інформаційних технологій, Національний аерокосмічний університет ім. М. Є. Жуковського «ХАI», Харків, Україна;

Alina Yelizieva - Candidate of Technical Sciences, Associate Professor of Computer Sciences and Information Technologies Department, National Aerospace University named after N. Ye. Zhukovskiy "KhAI", Kharkiv, Ukraine; e-mail: a.elizeva@khai.edu; ORCID ID: https://orcid.org/0000-0002-8228-9383.

Артюх Роман Володимирович - кандидат технічних наук, директор, Державне підприємство "Південний державний проектно-конструкторський та науково-дослідний інститут авіаційної промисловості", Харків, Україна;

Roman Artiukh - Candidate of Technical Sciences, Chief Executive Officer, State Enterprise "National Design \& Research Institute of Aerospace Industries", Kharkiv, Ukraine;

e-mail: roman.artyuh77@gmail.com; ORCID ID: https://orcid.org/0000-0002-5129-2221.

\title{
Розробка підсистеми інформаційної підтримки медичних лікувально-профілактичних центрів
}

\author{
М. В. Міланов, Ю. О. Лещенко, А. В. Слізєва, Р. В. Артюх
}

Анотація. Предметом дослідження статті є моделі і технології інформаційної підтримки медичного лікувальнодіагностичного центру (МЛДЦ). Метою $є$ зниження витрат і скорочення часу на організацію роботи медичного лікувально-діагностичного центру, шляхом застосування розроблених моделей та інформаційної системи. В роботі вирішуються наступні задачі: проведення аналітичного огляду існуючих інтегрованих медичних інформаційних систем; розробка моделі функціонування МЛДЦ; розробка програмного забезпечення для підсистеми інформаційної підтримки функціонування МЛДЦ, включаючи локальний формуляр лікарських препаратів. Для вирішення зазначених завдань були використані методи теорії алгоритмів, автоматних моделей, технології розробки програмних додатків. Отримані наступні результати. Проаналізовано існуючі медичні системи, які дозволяють автоматизувати бізнес-процеси лікувальних установ, виділені їх переваги та недоліки. Виділено функціональні підсистеми МЛДЦ, що автоматизують функції відділень медичного закладу. Для основних відділень МЛДЦ отримані автоматні моделі і вирази алгебри алгоритмів, що дозволяють представити в формалізованому вигляді процес функціонування медичного закладу. Сформована модель функціонування МЛДЦ на основі теорії автоматів і отримано вираз алгебри відносин, яке описує в формалізованої вигляді роботу медичного центру. Запропоновано структуру програмної системи інформаційної підтримки МЛДЦ. Розроблено навігаційна система web-pесурсу МЛДЦ. Розроблено діаграму прецедентів, що показує функціональні можливості основних категорій користувачів. Висновки: інформаційна підтримка МЛДЦ дозволить скоротити час на обслуговування пацієнтів за рахунок організованої послідовності дій співробітників відділів установи і скоротити ризик виникнення помилки при діагностиці за рахунок математико-статистичної обробки результатів проведення обстежень. Також розроблений формуляр лікарських препаратів, що дозволяє отримати пацієнтові рекомендації по використанню ліків на основі введених параметрів пошуку.

Ключов і слов а : медичний лікувально-діагностичний центр; автоматні моделі; алгебра алгоритмів; система інформаційної підтримки; діаграма прецедентів; веб-ресурс; формуляр лікарських препаратів.

\section{Разработка подсистемы информационной поддержки медицинских лечебно-профилактических центров}

М. В. Миланов, Ю. А. Лещенко, А. В. Елизева, Р. В. Артюх

Аннотация. Предметом исследования в статье являются модели и технологии информационной поддержки медицинского лечебно-диагностического центра (МЛДЦ). Целью является снижение затрат и сокращение времени на организацию медицинского лечебно-диагностического центра, путем применения разработанных моделей и информационной системы. В работе решаются следующие задачи: проведение аналитического обзора существующих интегрированных медицинских информационных систем; разработка модели функционирования МЛДЦ; разработка программного обеспечения для подсистемы информационной поддержки функционирования МЛДЦ, включая локальный формуляр лекарственных препаратов. Для решения указанных задач были использованы методы теории алгоритмов, автоматных моделей, технологии разработки программных приложений. Получены следующие результаты. Проанализированы существующие медицинские системы, которые позволяют автоматизировать бизнеспроцессы лечебных учреждений, выделены их преимущества и недостатки. Выделены функциональные подсистемы МЛДЦ, автоматизирующие функции отделений медицинского учреждения. Для основных отделений МЛДЦ получены автоматные модели и выражения алгебры алгоритмов, позволяющие представить в формализованном виде процесс функционирования медицинского учреждения. Сформирована модель функционирования МЛДЦ на основе теории автоматов и получено выражение алгебры отношений, описывающее в формализованной виде работу медицинского центра. Предложена структура программной системы информационной поддержки МЛДЦ. Разработана навигационная система web-pecypca МЛДЦ. Разработана диаграмма прецедентов, показывающая функциональные возможности основных категорий пользователей. Выводы: информационная поддержка МЛДЦ позволит сократить время на обслуживание пациентов 3 а счет организованной последовательности действий сотрудников отделов учреждения и сократить риск возникновения ошибки при диагностике за счет математико-статистической обработки результатов проведения обследований. Также разработан формуляр лекарственных препаратов, позволяющий получить пациенту рекомендации по использованию лекарств на основе введенных параметров поиска.

Ключевые слова: медицинский лечебно-диагностический центр; автоматные модели; алгебра алгоритмов; система информационной поддержки; диаграмма прецедентов; веб-ресурс; формуляр лекарственных препаратов. 